\title{
Coastal, offshore and migratory movements of South African right whales revealed by satellite telemetry
}

[Running head: Mate et al: Southern right whale movements]

B. R. Mate ${ }^{1 *}$, P. B. Best ${ }^{2}$, B. A. Lagerquist ${ }^{1}$, M. H. Winsor ${ }^{1}$

${ }^{1}$ Marine Mammal Institute, Oregon State University, 2030 SE Marine Science Drive, Newport, Oregon 97365, USA

${ }^{2}$ Mammal Research Institute, University of Pretoria, c/o Iziko South African Museum, P.O. Box 61, Cape Town, 8000 South Africa

*Email: bruce.mate@oregonstate.edu 


\section{ABSTRACT:}

In September 2001, 21 satellite-monitored radio tags were deployed on southern right whales in South African waters, 15 of which transmitted for 25-161 d. Most coastwise movement on the south coast occurred in a westerly direction with cow-calf pairs moving slowest. Three whales tagged on the west coast and one tagged on the south coast moved north into St Helena Bay, a probable feeding ground, where residence times were 36-100 d. Five animals tracked after leaving the coast maintained a bearing of $201-220^{\circ}$ before branching out over the southeast Atlantic from $37-60^{\circ} \mathrm{S}$ and between $13^{\circ} \mathrm{W}$ and $16^{\circ} \mathrm{E}$, travelling 3800-8200 km over the ensuing 53-110 d before transmissions ceased. Their locations were categorized as migrating or nonmigrating based on the relative orientation of the track and net speed. An average of $42 \%$ of non-migrating locations were between $37-45^{\circ} \mathrm{S}$ and $53 \%$ south of $52^{\circ} \mathrm{S}$, possibly associated with the Sub Tropical Convergence and Antarctic Polar Front respectively. Whaling data suggest right whales fed largely on copepods at the former and euphausiids at the latter. If the non-migrating locations represented feeding at these frontal zones, switching between them would seem to have obvious cost-benefit implications.

KEYWORDS: Foraging. Movements. Migration. Argos telemetry. Southern right whale. South Africa. Sub Tropical Convergence. Antarctic Polar Front 


\section{INTRODUCTION}

Most published accounts of the seasonal distribution and movements of southern right whales Eubalaena australis have relied on data from late eighteenth- and early nineteenth-century whaling (Townsend 1935), supplemented by information from illegal twentieth-century whaling (Tormosov et al. 1998). Interpretation of the resultant patterns of movement depends heavily on assumptions regarding the process of whaling and how it might have been affected by influences other than the abundance of whales (Best 1970, Best 1981, Bannister 2001). Other indirect lines of evidence used to investigate possible movement patterns have included stable isotope ratios in baleen (Best and Schell 1996) and combined genetic-stable isotopic analysis of skin (Valenzuela et al. 2009) More recently, direct evidence of individual movement has been obtained from photo-identification matches (Best et al. 1993, Best 1997, Bannister et al. 1999), but the timing, routes and speeds of migration still remain speculative. Such information is needed to establish patterns of habitat utilization and possibly identify areas of critical importance for the species.

In this paper we report on the movements of southern right whales on and away from the South African coast following the deployment of satellite tags in September 2001. The unprecedented use of this technology with southern right whales provided new insights into cow-calf movements along the coast, and the timing, routes, and migration speeds into offshore areas and different feeding grounds. 
In September 2001, satellite transmitters were deployed on 21 southern right whales in South African waters. The tags, equipped with Telonics ST-15 UHF Argos transmitters, were stainless steel cylinders $1.9 \mathrm{~cm}$ in diameter and $26.7 \mathrm{~cm}$ long, deployed from a crossbow and designed to be almost completely subdermal (see Mate et al. 2007 for details). The tags were programmed to transmit for 4 h every day with a subset of nine tags switching to transmitting 4 h every other day after $90 \mathrm{~d}$ to prolong battery life and allow tracking for longer periods (Table 1).

Sixteen of the tags were deployed in St Sebastian Bay on the south coast of South Africa between 8 and 13 September, and five outside Saldanha Bay on the west coast between 21 and 26 September (Fig. 1). Eight tags were placed on cows with calves, all in St Sebastian Bay, while the remaining 13 were placed on animals without calves. The sex of a tagged whale was established either because it had an accompanying calf (at the time of tagging or subsequent observations), from visual inspection of its genital area, or from a skin biopsy by polymerase chain reaction (PCR) amplification followed by TaqI digestion of the ZFX/ZFY region of the sex chromosomes (Palsbøll et al. 1992).

Tags were monitored by Argos Data Collection and Location Service receivers on NOAA TIROS-N weather satellites in sun-synchronous polar orbits. Locations were calculated by Argos from Doppler-shift data when multiple messages were received during the 7 to 16 min of a satellite's passage overhead. Argos-assigned accuracies of $150 \mathrm{~m}, 350 \mathrm{~m}$, and $1 \mathrm{~km}$ for high-quality locations (LC3, LC2, and LC1 respectively; 
see www.argos-system.org/html/system/faq_en.html\#LOCATION\%20ACCURACY) and an 11.5 km error around poor-quality locations (LC0, LCA, and LCB; based on results from previous tests; Mate et al. 1997) were used as radial errors. LCZ locations, locations on land farther than the assigned error distance from the ocean, poor-quality locations within $1 \mathrm{~h}$ of high-quality locations, and LC1 locations within 10 min of LC2 or LC3 locations were not used. If two poor-quality locations were less than $1 \mathrm{~h}$ apart, only the location providing the shortest distance between previous and subsequent acceptable locations was used. If two LC1 locations were $<10$ min apart, only the location providing the shortest distance between previous and subsequent acceptable locations was used. Minimum distances and speeds were then calculated between retained locations. Additional locations were eliminated if the speed between a location and the previous one was $>15 \mathrm{~km} / \mathrm{h}$ after adjusting for radial error. Of the 2132 locations obtained from all tags, 427 (20\%; Table 1) were rejected.

This method of filtering was chosen instead of other approaches such as Austin et al. (2003) and Freitas et al. (2008) because far fewer locations were received (average 2 per day, Table 1) as compared to 5.7 per d available in other studies (Austin et al. 2003). With the greater interval between locations resulting from only 4 h daily transmission cycles, it becomes problematic to use very aggressive filtering techniques. Additionally, locations on land were not automatically excluded as it could lead to an asymmetric offshore skewing of tracks. We recognize the challenge to the readers in interpreting graphics with locations on land but believe this approach provides the best analysis of movements especially along coastal areas. 
The remaining locations were combined with the GPS locations obtained when the tags were deployed to construct individual tracks. Distances between locations were calculated using the spherical law of cosines and, in combination with the elapsed time (recorded to the nearest second), were used to develop swimming speeds. Being net values, these are under-estimates of true speed over the ground (unless the animal is consistently swimming in one direction), but in combination with information about swimming direction, they are useful as an indication of animal behavior in different habitats.

Initial bearings between locations were calculated assuming a great-circle route. A measure of the angular dispersion of movement, $r$, has been calculated for each set of three consecutive initial bearings $\left(a_{1} \ldots a_{3}\right)$ where

$$
r=\sqrt{\left(\sum \cos \left(a_{i}\right) / n\right)^{2}+\left(\sum \sin \left(a_{i}\right) / n\right)^{2}}
$$

The value of $r$ varies inversely with the amount of dispersion so that $r=0$ indicates that there is total dispersion and $r=1.0$ that all the bearings are identical (Zar 1984).

Movements between locations for individuals that moved offshore were categorized as either migrating or non-migrating using criteria established from the visual examination of speed and $r$ distributions for all animals (assuming the majority of the movement along the coast would be non-migrating). Sections of track for individuals that moved offshore were categorized as migrating if $r>0.9$ and the net speed was $>$ $2 \mathrm{~km} / \mathrm{h}$ : otherwise the tracks would be considered as non-migrating. These criteria were derived from a comparison of the behavior of animals on the coast (presumably not migrating) and those offshore (see below). The value of $r>0.9$ was also used in a 
previous study describing the migration of humpback whales on the west coast of South Africa (Best et al. 1995).

The tags also provided a cumulative count of the number of surfacings made by the whales. A saltwater conductivity switch (SWS) established when a tag was above or below water and surfacings were determined when this SWS was above the surface of the water following a submergence of $6 \mathrm{~s}$ or more (Mate et al. 2007). Surfacing rates were calculated by dividing the number of surfacings between consecutive satellite passes by the elapsed time between these passes. Due to satellite schedules and tag duty cycles, elapsed times can range from less than 1 min to several days thus providing from near instantaneous to long-term integrated surfacing rates.

Surfacing rates were compared between cows with calves and adults without calves. An offshore surfacing rate was calculated for individuals that moved offshore and compared with the surfacing rate calculated for when they were in coastal areas. Surfacing rates were calculated for migrating and non-migrating track segments and were compared within individuals. All data were tested for normality (KolmogorovSmirnov test), equality of variances (Levine’s test), and autocorrelation (DurbinWatson test) prior to statistical comparisons performed using Generalized Linear Modeling (GLM) techniques. 
Six of the tags either failed to transmit at all or transmitted for $\leq 1 \mathrm{~d}$, so did not contribute to the results in this paper. Four of these six whales with failed tags were re-sighted 3-4 yr later, assuring their lack of transmissions were the result of electronic or mechanical failure (including detachment) and not whale mortality. Three of the cows with transmitting tags were seen from the air with their calves still in attendance 27-36 $\mathrm{d}$ following tagging so that their movements can reasonably be taken as representative of cow-calf pairs. In an analysis of right whales observed along the South Africa coastlines through 2005 (Best and Mate 2007), six of the tagged cows with calves were also subsequently seen with calves at intervals of 3-4 yr, similar to the observed intervals prior to tagging. These results suggest that tagging had no significant effect on reproductive success.

The 15 successful tags transmitted for periods of between 25 and $161 \mathrm{~d}$ (Table 1). Those on cows with calves lasted for a shorter period (25-57 d, $\bar{x}=37.0 \mathrm{~d}$, SD $=14.7$ $\mathrm{d}, n=4)$ than those on other classes (35-161 d, $\bar{x}=84.5 \mathrm{~d}, \mathrm{SD}=43.9 \mathrm{~d}, n=11$; Wilcoxon test, $P=0.022$ ).

Nine of the 15 tagged whales did not leave the coast before their tag stopped transmitting, 25-69 d ( $\bar{x}=43.6 \mathrm{~d}, \mathrm{SD}=16.3 \mathrm{~d}$ ) after deployment. Four of these were cows with calves, three were unaccompanied females, one was a male, and one was of undetermined sex. The remaining six whales (whose tags transmitted 64-161 d, $\bar{x}=$ $114.2 \mathrm{~d}, \mathrm{SD}=35.9 \mathrm{~d}$ and did not include any cows with calves) all eventually left the coast, and all but one were then tracked to oceanic feeding grounds. 
Because of the different geographic scales involved, and because the primary behaviors of the animals were likely to be different, results have been presented separately for coastal and offshore movements with development of criteria to categorize offshore movements into migrating and non-migrating segments.

\section{Coastal movements}

A time line has been constructed of the number of days after tagging (DAT) spent in various coastal areas or passing between coastal features (Fig. 1, Table 2). As the tags were deployed in two discrete blocks of time and space, the time lines were separated into whales tagged in St Sebastian Bay (Table 2A) and those tagged in Saldanha Bay (Table 2B).

Most movement after tagging in St Sebastian Bay occurred in a westerly direction: only three of the 10 animals moved into the adjacent segment to the east and then only for a maximum of $8 \mathrm{~d}$. Movement, however, was not always unidirectional; sometimes animals back-tracked into segments in which they had already been present (although some of these shifts may have been artifacts resulting from inaccurate locations). The westward movement of cow-calf pairs tended to be slower than for other classes: two cows were still in St Sebastian Bay 25 DAT or off De Hoop 27 DAT, while the other two finally rounded Cape Agulhas 23 and 43 DAT (Fig. 2). By contrast, while one animal of unknown sex was still off Struisbaai 37 DAT, four other whales (two females, a male and one of unknown sex) rounded Cape Agulhas between 10 and 16 DAT, while a fifth (male) had left the coast 18 DAT. The 
two cow-calf pairs tracked as far west as Walker Bay only arrived there 33 and 51 DAT, while four other animals reached the bay 12, 15, 20 and 22 DAT.

Two individuals (one male and one female) tagged in St Sebastian Bay travelled far enough west to round Cape Point and move onto the west coast. One (23034 - female) was tracked as far north as St Helena Bay, where it spent $39 \mathrm{~d}$ before transmissions ceased (Fig. 3). This is the longest period of continuous occupancy of a single segment of coast by an animal tagged in St Sebastian Bay.

The five whales tagged in Saldanha Bay consisted of two females and three males (Table 2B). One female travelled rapidly south and east, rounded Cape Point 3 DAT and Cape Agulhas 8 DAT, and reached St Sebastian Bay 10 DAT. Two days later it left the coast. This was the fastest transit of the coast of any of the tagged animals.

One of the three males, after a brief visit to St Helena Bay, travelled south round Cape Point and into False Bay, from where it left the coast 27 DAT. The remaining two males and the second female moved north within a few days of tagging and entered St Helena Bay (Fig. 3). Apart from an excursion into the Northern Cape by the female 831 (not shown in Fig. 3 for reasons of scale), these animals remained within the bay or in its vicinity for an extended period. The rate of information return for whale 831 (19 locations over $35 \mathrm{~d}$ ) is the lowest of all the tagged whales, with a very high proportion (12/19) of LCB locations, making it difficult to interpret its movements accurately. The two males (23031 and 23037) spent $100 \mathrm{~d}$ and 36-47 d (depending on interpretation of the incomplete location record) respectively within the bay before 
they left the coast. An inspection of the locations available for the four whales (including 23034) that spent time in St Helena Bay demonstrates an intense concentration in an area running roughly $50 \mathrm{~km}$ northeast from the headland at Cape Columbine (Fig. 3).

Coastal "residence time" and departure from the coast

Departure from the coast was documented for six whales, with departure points varying from the Cape Columbine area on the west coast (two animals) to Cape Point, Walker Bay, Cape Infanta and the Yservarkpunt region on the south coast. The first (a male) left on 24 September, the second (an unsexed individual) on 30 September, the third (female) on 4 October and the fourth (male) on 25 October. The last two animals (both male) only left the coast after visiting the feeding ground in St Helena Bay: the first left some time between 20 and 25 November, and the second on 8 January 2002. Coastal residence times since tagging were therefore 16, 22, 13, 29, 59-64, and $108 \mathrm{~d}$ respectively $(\bar{x}=41-42 \mathrm{~d})$.

Minimum residence times for the other tagged whales, whose transmitters ceased functioning before they left the coast, ranged from 25 to $57 \mathrm{~d}$ for four cow-calf pairs ( $\bar{x}=37 \mathrm{~d}$ ), and from 35 to $69 \mathrm{~d}(\bar{x}=48.8 \mathrm{~d}$ ) for five other whales, one of which was a male (66 d) and three were female (35, 36 and 69d).

Speeds, angular dispersion, and criteria for categorizing movement 
Net speeds of movement documented for cow-calf pairs were generally low, ranging up to $10.5 \mathrm{~km} / \mathrm{h}$ but with $88 \%$ of the net speeds being $<2 \mathrm{~km} / \mathrm{h}$ and $96 \%<5 \mathrm{~km} / \mathrm{h}$. The mean net speeds for the cow-calf pairs ranged from $0.6-1.5 \mathrm{~km} / \mathrm{h}$ with a mean of 1.1 $\mathrm{km} / \mathrm{h}$. While close to shore, other classes of whale exhibited a somewhat similar range of net speeds, but with relatively fewer in the slowest range class $(<0.5 \mathrm{~km} / \mathrm{h})$ and more in the higher classes; individual's mean net speeds ranged from 1.0-2.8 km/h with an overall mean of $1.6 \mathrm{~km} / \mathrm{h}(\mathrm{SD}=0.59 \mathrm{~km} / \mathrm{h}, n=11)$. Such net speeds contrasted markedly with those seen once the whales moved offshore $(n=5)$ where individual's mean net speeds ranged from $2.8-3.8 \mathrm{~km} / \mathrm{h}(\bar{x}=3.3 \mathrm{~km} / \mathrm{h}, \mathrm{SD}=0.37$ km/h, Fig. 4).

The distribution of $r$ values for both cow-calf pairs and other whale classes in coastal waters has a distinct mode at $0.3-0.4$, indicative of little concerted directionality of movement (Fig. 5). The distribution of $r$ values for whales that moved offshore is quite different, with a small mode also at 0.3-0.4 but a much larger one at values of 0.9-1.0. Choosing a value of $r=0.9$ would therefore seem to be a useful way of discriminating between whales that are on the move and those that are indulging in some other activity (feeding, resting, reproduction). However, $r$ values of this magnitude also occurred, presumably by chance, in coastal waters where right whales are generally not considered to be migrating. In order to discriminate between whales with a high $r$ value that are actively on the move and those that are not, the percentage frequency distribution of net speeds for animals while on the coast has been compared with that for individuals offshore for cases where $r \geq 0.9$. The distributions are clearly different (Fig. 6), with 71\% of the speeds recorded for animals travelling 
with this directionality inshore being less than $2 \mathrm{~km} / \mathrm{h}$, and $83 \%$ of the speeds for animals offshore being in excess of $2 \mathrm{~km} / \mathrm{h}$.

The criteria adopted for determining that a section of track represents migrating behavior have therefore been chosen as locations with an $r$ value $\geq 0.9$ and a net speed $\geq 2 \mathrm{~km} / \mathrm{h}$. Because the $r$ value is a composite of the information from three sequential locations, a location satisfying these criteria and the locations before and after are categorized as migrating. All other locations are categorized as non-migrating.

\section{Offshore movements}

The movements of five (one female, three males and one of unknown sex) of the six tagged right whales that departed the coast could be monitored; the transmitter of the sixth only produced one location of reasonable quality following departure. The initial courses followed by the whales were surprisingly consistent. For the first 700-800 km of their journey away from the coast, the distance-weighted mean of bearings between locations for all five animals only varied from $201.2-220.5^{\circ}$, with a mean of $211.2^{\circ}$ (Table 3). Irrespective of when or from where they left the coast, all whales initially headed southwest into the South Atlantic. After this initial dispersion, however, their behavior varied greatly. Over the ensuing 53-110 d, each animal travelled between 3800 and 8200 km, independently ranging over a large part of the South East Atlantic, from $37-60^{\circ} \mathrm{S}$ and between $13^{\circ} \mathrm{W}$ and $16^{\circ} \mathrm{E}$, or roughly an area of 5.3 million sq $\mathrm{km}$. 
Some portions of the offshore tracks were characterized by successive migrating locations for periods of 9-22 d, during which time the animals moved in a southerly direction away from the South African coastline; we have termed these concerted southward migrations (Table 3). For these episodes the overall track lengths have been obtained by summing the distances between locations, and dividing by the known time elapsed to give a mean speed over the ground. Three of the tagged whales (836, 848, and 23031) maintained mean speeds of 5.1-6.5 km/h over 9-15 d, while the fourth (839) maintained a mean of $4.4 \mathrm{~km} / \mathrm{h}$ over $22 \mathrm{~d}$. Whale 4172 did not provide enough sequential migrating locations to be included in this analysis.

The five whales adopted three different strategies for dispersal (Fig. 7). Two whales (848 and 23031) travelled more or less directly to high latitudes, with $77 \%$ and $79 \%$ of their offshore locations coming from below $50^{\circ} \mathrm{S}$. All locations from another whale (4172) were north of $46^{\circ} \mathrm{S}$ while the final two (836 and 839) moved between localities south of $50^{\circ} \mathrm{S}$ and north of $45^{\circ}$ (up to $40^{\circ} \mathrm{S}$ ). One of the latter two whales (839) made a second sortie down to nearly $60^{\circ} \mathrm{S}$ before its transmitter stopped.

We considered non-migrating offshore locations as probable feeding locations, although this does not exclude the possibility of other non-locomotory behavior such as socializing or resting. Per individual these represent $29-75 \%$ of all locations received, with the two whales that migrated between high and low latitude zones having appreciably fewer such locations (29-36\%) than the other three (60-75\%). 
Illustrating the distribution of these non-migrating locations by latitude over time from September to March makes the separation of the probable feeding zones clear

(Fig. 8). The average of the five whale's proportions of non-migrating locations located between $37-45^{\circ} \mathrm{S}$ was $42 \%, 53 \%$ south of $52^{\circ} \mathrm{S}$, and only $5 \%$ in the intervening $7^{\circ}$ of latitude. This separation persisted throughout the period of the feeding season monitored. During November/December, animals feeding in the northern zone appeared to be stratified into two groups about $2-3^{\circ}$ of latitude apart, while those feeding in the southern zone seemed to shift gradually into higher latitudes as the season advanced.

\section{Surfacing rates}

Surfacing rates were computed from cumulative counts of surfacings between satellite passes using time segments from 0.24 min up to 119 h. Rates ranged from 3-327 surfacings/h throughout the tracking periods. An outlier analysis for each whale was performed using a maximum normalized residual test (Sokal and Rohlf 1981). All rates $>150$ surfacings/h were considered outliers $(n=14$, $P$ 's ranging from $<.00001$ 0.016) and not used in further analyses. Data from the five whales that moved offshore were analyzed in detail to determine if rates varied between coastal and offshore. Surfacing rates for two of these whales (4172 and 23031) were log transformed to normalize data. Significant autocorrelation was detected for all whales (Durbin-Watson statistic $p<0.0001$ ) and was corrected by the Cochrane-Orcutt procedure (Neter et al. 1989). Variances of the transformed values were unequal between whales so each whale was analyzed individually. Modified Bonferroni 
adjusted levels of significance (Jaccard and Wan 1996) were used for Generalized Linear Model (GLM) comparisons. Four of the five whales (836, 839, 4172 and 23031) had significantly higher surfacing rates while offshore than in coastal waters (GLM P's ranging from <0.0001-0.031). The fifth whale (848) had the opposite pattern, with significantly higher rates in coastal waters than offshore (GLM $P<$ 0.0001).

Further comparisons subdividing offshore rates into migrating and non-migrating categories (using the previously-mentioned location categorizations) showed significant differences between coastal, migrating, and non-migrating surfacing rates for three whales (836 GLM $P=0.0003,848$ GLM $P \leq 0.0001$, and 23031 GLM $P \leq$ 0.0001; Table 4), however there was no consistent pattern in the differences between whales.

Mean surfacing rates in coastal waters were significantly higher (t-test, $P=0.007$ ) for cows with calves $(\bar{x}=70 \pm 6.5$ surfacings/h, $n=4)$ than for adults without calves $(\bar{x}$ $=45 \pm 3.9$ surfacings/h, $n=11$, excluding whale 1385 for which there were only 3 data points). Because no cows with calves provided offshore rates, additional comparisons were not possible.

\section{DISCUSSION}

The use of satellite tags in this study provided an unprecedented opportunity for gaining insight into the patterns of movement of southern right whales on and away 
from the South African coastline, information that was otherwise unavailable for any population of southern right whales. By integrating satellite tracking information with that from aerial surveys, photo-identification, and historical catches, a more complete and detailed description of movements is possible.

Locations from cows with calves were grouped in specific areas along the coastline, especially in St Sebastian Bay, off De Hoop, in Struisbaai, around Quoin Point, in Walker Bay and Sandown Bay, and corresponded to known concentration areas for cow-calf pairs (Elwen and Best 2004). The movements detected between areas suggest that these are areas of congregation where cow-calf pairs tend to linger to socialize or because conditions are somehow favorable for calf development.

The seasonal shift of three of the cow-calf pairs to the west confirms what was suspected from re-sightings on aerial surveys (Best 2000), but could not be confirmed due to bias in the survey protocol. Most of the movements of the other whales tagged in St Sebastian Bay also occurred in a westerly direction. A similar westward shift of right whales along the southern Australian coast in winter was suggested by nineteenth-century whalers (Bannister 1986), and subsequently confirmed by the movements of individually identified animals of both sexes, as part of a postulated annual anti-clockwise “circulation” of whales south of Australia (Burnell 2001).

The south-westerly movement away from the coast by all five of the animals that were tracked offshore might suggest that there is some link between the westward coastal shift in winter and the south-westerly departure from the coast in spring. 
Given the prevailing West Wind Drift in the Southern Ocean south of Africa, utilization of feeding grounds to the west of the continent in summer (with a relatively short cross-current return transit to the north in winter) might make energetic sense, and would be consistent with the circulation pattern proposed by Burnell (2001).

Our estimates of coastal residence times, although minimum values, are still important. They are not as subject to spatial or temporal limitations as earlier estimates based on photo-identification, and for some individuals an exact date of departure is known. Not unexpectedly, given that neither arrival nor departure dates were monitored, the estimated residence times for cow-calf pairs (25-57 d, $\bar{x}=37 \mathrm{~d}$ ) are much lower than those published from Australia $(\bar{x}=71 \mathrm{~d}$, maximum $108 \mathrm{~d}$, Burnell and Bryden 1997) or indeed from South Africa (12-105 d, $\bar{x}=59 \mathrm{~d}$, Best 2000) and must be considered negatively biased. Tagged cow-calf pairs had a shorter tag life than other classes probably as a result of tag damage arising from the strong thigmotactic behavior shown by neonatal right whales towards their mothers.

Although results are not directly comparable due to differing methodologies and assumptions, coastal residence time estimates for unaccompanied whales are surprisingly high (13-108 d, $\bar{x}=41-42 \mathrm{~d}$ for those with known departure times, and 35-69 d, $\bar{x}=49 \mathrm{~d}$ for others) in this study compared to those published for Australia ( $\bar{x}=20.4 \mathrm{~d}$, max $93 \mathrm{~d}$, Burnell and Bryden 1997). Part of this difference may be the inclusion of data for whales that visited St Helena Bay in spring: if these are excluded, the values for unaccompanied whales become $13-29 \mathrm{~d}(\bar{x}=20 \mathrm{~d})$ for those with known departure times, and 36-66 d ( $\bar{x}=47 \mathrm{~d})$ for others. 
Net speeds recorded during concerted southward movements of tagged whales (4.4$6.5 \mathrm{~km} / \mathrm{h}$ ) are the first for migrating southern right whales, and are higher than all but one of the speeds recorded for North Atlantic right whales by Mate et al. (1997), although that study did not distinguish migrating from non-migrating or probable feeding sections of the tracks. The individual mean net speeds estimated in coastal waters for the tagged whales $(0.6-2.8 \mathrm{~km} / \mathrm{h})$ are similar to the average and net swimming speeds for 34 groups of right whales in South African waters recorded by theodolite from shore $(0.4-3.6 \mathrm{~km} / \mathrm{h}, \bar{x}=1.7 \mathrm{~km} / \mathrm{h}$ and $0.01-3.1 \mathrm{~km} / \mathrm{h}, \bar{x}=1.0 \mathrm{~km} / \mathrm{h}$ respectively, Best 2000). Net speeds estimated in the same study, from re-sightings of individual cow-calf pairs at intervals of one day $(n=17)$, ranged from $0.4-2.9 \mathrm{~km} / \mathrm{h}$, with a mean of $1.3 \mathrm{~km} / \mathrm{h}$. As coastal speeds of tagged whales are of a similar magnitude, and are well below the speeds recorded while offshore, it suggests that the satellite-derived data (although still conservative) are not unduly biased by location error or the interval between data points.

The ranges for surfacing rates reported here are within those reported in the literature for other baleen whale species (21-88 surfacings /h for humpback whales, Lagerquist et al. 2008; 60 surfacings/h for blue whales, Lagerquist et al. 2000; 64 surfacings/h for fin whales, Kopelman and Sadove, 1995; 18-47 surfacings/h for bowhead whales, Krutzikowsky and Mate, 2000; 63 surfacings/h for gray whales, Würsig et al. 1986). It is not surprising that surfacing rates of cows with calves were higher than the rates of adults without calves. This likely reflects the tendency for the mother to remain with the calf that has to surface more frequently than an adult. Baumgartner and Mate (2003) found longer surface intervals for North Atlantic right whale calves and 
females with calves than for other age/reproductive classes (excluding a pregnant female) and suggested that the surfacing behavior of females with calves is governed by the calf's diving capabilities.

Surfacing rates have been shown to be higher during feeding than during other behaviors for lunge-feeding rorquals, due, potentially, to the high energetic cost of lunging (Acevedo-Gutiérrez et al. 2002, Goldbogen et al. 2008). The skim or continuous ram feeding strategy of right whales is believed to be less costly than lunge-feeding (Croll et al. 2001), and may result in lower surfacing rates for feeding right whales than those engaged in other behaviors. Individual variation in this study was such that no consistent pattern was exhibited in surfacing rates. While four of the five whales that migrated away from the coast had higher surfacing rates offshore than in coastal waters, one had the opposite pattern. Of the former four whales, one (836) showed higher rates for migrating than during non-migrating segments or time in coastal waters, while another (848) showed higher rates in coastal waters than during migrating or non-migrating segments. A third whale (23031) had higher rates during non-migrating sections, lower rates during time in coastal waters, and intermediate rates during migrating sections. This latter whale was the animal that spent 100 days in St Helena Bay after tagging, presumably feeding. Perhaps different prey encountered by this whale in the two feeding areas, coastal and offshore (described below), contributed to different feeding behavior and hence, different surfacing rates in these areas. Interpretation of the surfacing rate data should be treated with caution, however, given that the exposure of the tag may depend to some extent on its position on the body, and that the data are calculated over time spans 
averaging 7-11 h per whale, during which the activity patterns of the animal may change.

Perhaps the most interesting and unexpected result of the tagging was the discovery of the different feeding areas available to southern right whales in the South Atlantic and the variety of strategies used to exploit them.

The concentration of the tag locations in St Helena Bay corresponds with the position of a well-known upwelling plume that extends northwards from Cape Columbine and curves eastwards towards the coast in response to cyclonic wind curvature (TauntonClark 1985). This region exhibits some of the highest levels of zooplankton abundance on the west coast (Verheye et al. 1998), and recent observations have confirmed the presence of whales feeding (largely on copepods) in the vicinity of the clump of tag locations in spring and early summer. Additionally, St Helena Bay was a late eighteenth-century whaling ground (Best 2006), with catches concentrated in summer and autumn rather than in winter and spring, indicating that its principal function was unlikely to be a nursery ground. This area is a potentially important feeding ground for southern African right whales and may account for the amount of time spent there by the four tagged whales, although the exact number of animals using it has yet to be established.

Of the two offshore zones utilized by the tagged right whales in summer (Fig. 8), the more northerly seems to be associated with the Sub Tropical Convergence (STC) which in the South Atlantic has a mean position of $41^{\circ} 40^{\prime} \mathrm{S}$ and is known for its high 
primary productivity (Ansorge and Lutjeharms 2007). In the vicinity of Tristan da Cunha separate fronts have been associated with the northern and southern boundaries of the STC, with the northern front located at $35-37.3^{\circ} \mathrm{S}$ and the southern at approximately $39^{\circ} \mathrm{S}$, although these positions may shift seasonally by up to $2.5^{\circ}$ of latitude (Smythe-Wright et al. 1998). It is possible that the simultaneous "shadowing” of the non-migrating locations in the northern zone seen in November/December (Fig. 8) represents the three tagged whales foraging at the northern and southern boundaries of the STC, some $3^{\circ}$ of latitude apart.

The two zones could possibly be associated with different potential prey types. Between 1951 and 1971, the stomachs of southern right whales examined north of $40^{\circ}$ S were dominated by copepods (91.7\%), while of those between $40-50^{\circ} \mathrm{S}, 71.4 \%$ contained copepods, 24.3\% euphausiids and the remainder small crustaceans (Tormosov et al. 1998), suggesting that the whales' principal prey in this feeding zone was copepods. A similar latitudinal succession of prey-types has been recorded for the Antarctic sei whale, and given the similar feeding behavior and distribution of the two whales it is possible that the same food species are involved. Copepods (especially Calanus tonsus and C. simillimus) occurred in the sei whale diet from about $40^{\circ} \mathrm{S}$ to the middle of the SubAntarctic zone $\left(51-52^{\circ} \mathrm{S}\right)$. In the northern part of the range copepods were the dominant food type but were supplanted by smaller euphausiids such as Euphausia vallentini or the amphipod Themisto gaudichaudii in the southern part closer to $50^{\circ} \mathrm{S}$ (Kawamura 1974). 
The more southerly non-migrating zone, running from $52-57^{\circ} \mathrm{S}$ (Fig. 8), may correspond to the position of the Antarctic Polar Front (APF, or Antarctic Convergence). Here northward-moving Antarctic water sinks below warmer subantarctic water, forming strong horizontal gradients in temperature and salinity: its average location is at $52-53^{\circ} \mathrm{S}$, although south of Africa it may lie at only $50^{\circ} 47^{\prime} \mathrm{S}$ (Ansorge and Lutjeharms 2007). South of $50^{\circ}$ S, right whale stomach contents consisted almost entirely (99.4\%) of unidentified euphausiids (Tormosov et al. 1998). Sei whales at these latitudes were feeding to the north on Themisto gaudichaudii and to the south on Euphausia superba (Kawamura, 1974), and these remain the most likely targets for right whales feeding in this zone.

Almost half (9/19) of the non-migrating locations found in the intermediate zone between $45-52^{\circ} \mathrm{S}$ occurred in a single episode by whale 848 between 19 and 30 October 2001, when it was some $60 \mathrm{mi}$ south of the Meteor Seamount (at $48^{\circ} \mathrm{S}$ and $8^{\circ}$ 30’ E). This area was also traversed a few days earlier by whale 839 and about a week later by whale 836, and although neither of the latter two whales tarried in the region, the intersection of all three tracks in this location suggests that the vicinity of the seamount may hold some significance for southern right whales in late spring, as has been indicated for blue whales in the North Pacific (Moore et al. 2002).

The five southern right whales tracked offshore displayed four different foraging strategies involving three different feeding zones (APF, STC, St Helena Bay). Two individuals (836 and 839) travelled firstly to the APF and then to the STC, with 839 subsequently returning to the APF. One individual (848) travelled to the APF and 
remained there. Another individual (4172) seemed to only visit the STC, while the last (23031) spent $100 \mathrm{~d}$ in St Helena Bay before moving directly to the APF. Some of these strategies may have converged or new ones emerged but since the animals were not tracked for an entire summer season, these possibilities remain unknown.

The strategy of moving between feeding zones had obvious cost-benefit implications, as it resulted in a substantially lower incidence of non-migrating locations. The reduction in feeding frequency that this suggests might be compensated for by a higher density or energy content of prey on the new ground, but the mechanisms by which right whales are able to make such long-range decisions remains a subject of future research.

\section{ACKNOWLEDGEMENTS}

We thank E. Beukes and M. Thornton for kindly allowing B.A.L. to drive their boat during tagging and M. L. Mate for recording tag applications on video to evaluate tag attachment characteristics. Accommodation at the Military Academy, Saldanha, was provided by arrangement with the Dean, Prof J. Malan, and the Commandant, Brigadier-General S. Mollo. C. Veness (Movable Type Scripts, Cambridge, UK) provided invaluable assistance with calculating distances and bearings between locations. P.B.B. acknowledges the support of the National Research Foundation of South Africa (GUN number 2047517). B.R.M. acknowledges the support of the National Oceanic and Atmospheric Administration through the Northeast Consortium, based at the University of New Hampshire (Grant \# NA16FL1324), the U.S. Office of 
Naval Research, and donors to the Oregon State University Endowed Marine

Mammal Program. All tagging was done under a permit issued to P.B.B. by the South African Department of Environmental Affairs and Tourism in terms of Regulation 58 of the Marine Living Resources Act (no. 18 of 1998) dated 10 January 2001. The Oregon State University Animal Care and Use Committee approved this research. 


\section{LITERATURE CITED}

Acevedo-Gutiérrez, A., D. A. Croll and B. R. Tershey. 2002. High feeding costs limit dive time in the largest whales. Journal of Experimental Biology 205:1747-1753.

Ansorge, I. J., and J. R. E. Lutjeharms. 2007. The cetacean environment off southern Africa. Pages 5-13 in P. B. Best, ed. Whales and Dolphins of the southern African Subregion. Cambridge University Press, Cape Town.

Austin, D., J. I. Mcmillan and W. D. Bowen. 2003. A three-stage algorithm for filtering erroneous Argos satellite locations. Marine Mammal Science 19:371383.

Bannister, J. L. 1986. Southern right whales: status off Australia from twentiethcentury 'incidental' sightings and aerial survey. Report to the International Whaling Commission. Special Issue 10:153-158.

Bannister, J. 2001. Status of southern right whales (Eubalaena australis) off Australia. Journal of Cetacean Research and Management. Special Issue 2:103-110.

Bannister, J. L., L. A. Pastene and S. R. Burnell. 1999. First record of movement of a southern right whale (Eubalaena australis) between warm water breeding 
grounds and the Antarctic Ocean, south of $60^{\circ} \mathrm{S}$. Marine Mammal Science $15: 1337-1342$.

Baumgartner, M. F., and B. R. Mate. 2003. Summertime foraging ecology of North Atlantic right whales. Marine Ecology Progress Series 264:123-135.

Best, P. B. 1970. Exploitation and recovery of right whales Eubalaena australis off the Cape Province. Investigative Reports of the Division of Sea Fisheries South Africa 80:1-20.

Best, P. B. 1981. The status of right whales (Eubalaena glacialis) off South Africa, 1969-1979. Investigative Report of the Division of Sea Fisheries Institute South Africa 123:1-44.

Best, P. B. 1997. Whale watching in South Africa. The southern right whale. Mammal Research Institute, Pretoria.

Best, P. B. 2000. Coastal distribution, movements and site fidelity of right whales Eubalaena australis off South Africa, 1969-1998. South African Journal of Marine Science 123:43-55.

Best, P. B. 2006. The presence of right whales in summer on the west coast of South Africa: the evidence from historical records. African Journal of Marine Science 28:159-166. 
Best, P. B., R. Payne, V. Rowntree, J. T. Palazzo and M. C. Both. 1993. Long range movements of South Atlantic right whales Eubalaena australis. Marine Mammal Science 9:227-234.

Best, P .B., K. Sekiguchi and K. P. Findley. 1995. A suspended migration of humpback whales (Megaptera noveangliae) on the west coast of South Africa. Marine Ecology Progress Series 118:1-12.

Best, P. B., and D. M. Schell. 1996. Stable isotopes in southern right whale (Eubalaena australis) baleen as indicators of seasonal movements, feeding and growth. Marine Biology 124:483-494.

Best, P. B., and B. R. Mate. 2007. Sighting history and ovservations of souther right whales following satellite tagging off South Africa. Journal of Cetacean and Management 9(2): 111-114.

Burnell, S. R. 2001. Aspects of the reproductive biology, movements and site fidelity of right whales off Australia. Journal of Cetacean Research and Management. Special Issue 2:89-102.

Burnell, S. R., and M. M. Bryden. 1997. Coastal residence periods and reproductive timing in southern right whales, Eubalaena australis. Journal of Zoology 241:613-621. 
Croll, D. A., A. Acevedo- Gutiérrez, B. R. Tershy and J. Urbán-Ramirez. 2001. The diving behavior of blue and fin whales: is dive duration shorter than expected based on oxygen stores? Comparative Biochemistry and Physiology Part A: Molecular \& Integrative Physiology 129:797-809.

Elwen, S. H., and P. B. Best. 2004. Environmental factors influencing the distribution of southern right whales (Eubalaena australis) on the south coast of South Africa I: Broad scale patterns. Marine Mammal Science 20:567-582.

Freitas, C., C. Lydersen, M. A. Fedak and K. M. Kovacs. 2008. A simple new algorithm to filter marine mammal Argos locations. Marine Mammal Science 24:315-325.

Goldbogen, J. A., J. Calambokidis, D. A. Croll, J. T. Harvey, K. M. Newton, E. M. Oleson, G. Schorr and R. E. Shadwick. 2008. Foraging behavior of humpback whales: kinematic and respiratory patterns suggest a high cost for a lunge. The Journal of Experimental Biology 211:3712-3719.

Jaccard, J., and C. K. Wan. 1996. LISREL approaches to interaction effects in multiple regression. Sage University Paper series on Quantitative Applications in the Social Sciences, series no. 07-114, Thousand Oaks, CA. 
Kawamura, A. 1974. Food and feeding ecology in the southern sei whale. Scientific Reports of the Whales Research Institute 26:25-144.

Kopelman, A. H., and S. S. Sadove. 1995. Ventilatory rate differences between surface-feeding and non-surface feeding fin whales (Balaenoptera physalus) in the waters off eastern Long Island, New York, U.S.A., 1981-1987. Marine Mammal Science 11:200-208.

Krutzikowsky, G. K., and B. R. Mate. 2000. Dive and surfacing characteristics of bowhead whales (Balaena mysticetus) in the Beaufort and Chukchi seas. Canadian Journal of Zoology 78:1182-1198.

Lagerquist, B. A., K. M. Stafford and B. R. Mate. 2000. Dive characteristics of satellite-monitored blue whales (Balaenoptera musculus) off the central California coast. Marine Mammal Science 16:375-391.

Lagerquist, B., B. Mate, J. G. Ortega-Ortiz, M. Winsor and J. Urbán-Ramirez. 2008. Migratory movements and surfacing rates of humpback whales (Megaptera novangliae) satellite tagged at Socorro Island, Mexico. Marine Mammal Science 24:815-830.

Mate, B. R., S. L. Nieukirk and S. D. Kraus. 1997. Satellite-monitored movements of the northern right whale. Journal of Wildlife Management 61:1393-1405. 
Mate, B. R., R. Mesecar and B. Lagerquist. 2007. The evolution of satellite-monitored radio tags for large whales: one laboratory’s experience. Deep-Sea Research Part II-Topical Studies in Oceanography 54:224-247.

Moore, S. E., W. A. Watkins, M. A. Daher and J. R. Davies. 2002. Blue whale habitat associations in the Northwest Pacific: analysis of remotely sensed data using a Geographic Information System. Oceanography 15(3): 2-25.

Neter, J., W. Wasserman and M. H. Kutner. 1989. Applied Linear Regression Models. Richard D. Irwin, Inc., Homewood, IL.

Palsbøll, P. J., A. Vader, I. Bakke and M. R. El-Gewely. 1992. Determination of gender in cetaceans by the polymerase chain reaction. Canadian Journal of Zoology 70:2166-2170.

Smythe-Wright, D., P. Chapman, C. Duncombe Rae, L. V. Shannon and S. M. Boswell. 1998. Characteristics of the South Atlantic subtropical frontal zone between $15^{\circ} \mathrm{W}$ and $5^{\circ} \mathrm{E}$. Deep-Sea Research Part I-Oceanographic Resesarch Papers 45:167-192.

Sokal, P. R., and F. J. Rohlf. 1981. Biometry. W. H. Freeman and Company., New York. 
Taunton-Clarke, J. 1985. The formation, growth and decay of upwelling tongues in response to the mesoscale wind field during summer. Pages 47-61 in L. V. Shannon, ed. South African Ocean Colour and Upwelling Experiment. Sea Fisheries Research Institute, Cape Town.

Tormosov, D. D., Y. A. Mikhaliev, P. B. Best, V. A. Zemsky, K. Sekiguchi and R. L. Brownell, Jr. 1998. Soviet catches of southern right whales Eubalaena austalis, 1951-1971: Biological data and conservation implications. Biological Conservation 86:185-197.

Townsend, C. H. 1935. The distribution of certain whales as shown by logbook records of American whale ships. Zoologica 19:1-50.

Valenzuela, L. O., M. Sironi, V. J. Rowntree and J. Seger. 2009. Isotopic and genetic evidence for culturally inherited site fidelity to feeding grounds in southern right whales (Eubalaena australis). Molecular Ecology 18:782-791.

Verheye, H. M., A. J. Richardson, L. Hutchings, G. Marska and D. Gianakouras. 1998. Long-term trends in the abundance and community structure of coastal zooplankton in the southern Benguela system. South African Journal of Marine Science 19:317-332. 
Würsig, B., R. S. Wells and D. A. Croll. 1986. Behavior of gray whales summering near St. Lawrence Island, Bering Sea. Canadian Journal of Zoology 64:611621.

Zar, J. H. 1984. Biostatistical analysis. Prentice-Hall, Inc., Englewood Cliffs, New Jersey. 
Figure Captions:

Figure 1. Geographic areas of the south-western coastline of South Africa. Arrows point to the two areas from which tags were deployed.

Figure 2. Locations of four right whales, Eubalaena australis, with calves tagged in St Sebastian Bay on the South African coast, September to November 2001.

Figure 3. Locations of four satellite-tagged right whales, Eubalaena australis, in St Helena Bay area of South Africa, September 2001 - January 2002.

Figure 4. Percent frequency distribution of net speeds of movement of tagged southern right whales, Eubalaena australis, comparing cow-calf pairs with other classes in coastal and offshore waters.

Figure 5. Percent frequency distribution of $r$-values for direction of movement of tagged southern right whales, Eubalaena australis, comparing cow-calf pairs with other classes in coastal and offshore waters.

Figure 6. The percent frequency distribution of net speeds of tagged right whales, Eubalaena australis, for locations with $r$ values of 0.9 or more, compared between animals in coastal waters and those offshore. 
Figure 7. Locations of five tagged right whales, Eubalaena australis, after leaving the South African coastline, September 2001 - March 2002.

Figure 8. Seasonal trends in the offshore latitudinal distribution of non-migrating locations of tagged right whales, Eubalaena australis, September 2001 - March 2002. 
Table 1. Deployment details, number of days tracked, and number of locations for 21 southern right whales, Eubalaena australis, satellite tagged off South Africa, 2001 (STSB = St Sebastian Bay, SB = Saldanha Bay; H-Q are high-quality locations with classes LC1, LC2 or LC3, P-Q are poor-quality locations with classes LC0, LCA, or LCB; Duty Cycle 1 - On for 4 h/d, 2 - On for 4 h/d then On for 4 h every other day after $90 \mathrm{~d}$ ).

\begin{tabular}{|c|c|c|c|c|c|c|c|c|c|c|}
\hline \multirow[b]{2}{*}{ Tag } & \multirow[b]{2}{*}{ Sex/Class } & \multirow{2}{*}{$\begin{array}{c}\text { Deploy } \\
\text { date }\end{array}$} & \multirow{2}{*}{$\begin{array}{l}\text { Deploy } \\
\text { location }\end{array}$} & \multirow{2}{*}{$\begin{array}{c}\text { Days } \\
\text { tracked }\end{array}$} & \multicolumn{3}{|c|}{$\begin{array}{c}\text { Number of filtered } \\
\text { locations }\end{array}$} & \multirow{2}{*}{$\begin{array}{c}\text { Number } \\
\text { Rejected } \\
(\%)\end{array}$} & \multirow{2}{*}{$\begin{array}{c}\text { Average } \\
\text { Locations } \\
\text { per day }\end{array}$} & \multirow{2}{*}{$\begin{array}{l}\text { Duty } \\
\text { Cycle }\end{array}$} \\
\hline & & & & & H-Q & P-Q & Total & & & \\
\hline 823 & Cow + calf & 08-Sep-01 & STSB & 25 & 22 & 19 & 41 & 4 (9) & 1.8 & 2 \\
\hline 824 & unknown & 08-Sep-01 & STSB & 0 & & & 0 & & $\mathrm{n} / \mathrm{a}$ & 2 \\
\hline 825 & unknown & 08-Sep-01 & STSB & 38 & 32 & 49 & 81 & $24(23)$ & 2.8 & 2 \\
\hline 826 & Female & 08-Sep-01 & STSB & 36 & 10 & 22 & 32 & $4(11)$ & 1.0 & 2 \\
\hline 827 & Cow + calf & 08-Sep-01 & STSB & 27 & 28 & 17 & 45 & $13(22)$ & 2.1 & 2 \\
\hline 831 & Female & 22-Sep-01 & SB & 35 & 2 & 17 & 19 & $9(32)$ & 0.8 & 1 \\
\hline 834 & Cow + calf & 12-Sep-01 & $\begin{array}{l}\text { STSB } \\
\text { ST }\end{array}$ & 0 & & & 0 & & $\mathrm{n} / \mathrm{a}$ & 1 \\
\hline 835 & Cow + calf & 13-Sep-01 & STSB & 0 & & & 0 & & $\mathrm{n} / \mathrm{a}$ & 1 \\
\hline 836 & Female & 21-Sep-01 & SB & 81 & 68 & 112 & 180 & $44(20)$ & 2.8 & 1 \\
\hline 837 & Female & 12-Sep-01 & STSB & $<1$ & 1 & & 1 & $0(0)$ & $\mathrm{n} / \mathrm{a}$ & 1 \\
\hline 838 & Male & 12-Sep-01 & STSB & 66 & 48 & 52 & 100 & $14(12)$ & 1.7 & 1 \\
\hline 839 & unknown & 08-Sep-01 & STSB & 119 & 54 & 108 & 162 & 35 (18) & 1.7 & 2 \\
\hline 843 & Cow + calf & 08-Sep-01 & STSB & 39 & 77 & 27 & 104 & $34(25)$ & 3.5 & 2 \\
\hline 847 & Cow + calf & 12-Sep-01 & STSB & 57 & 65 & 58 & 123 & 26 (17) & 2.6 & 1 \\
\hline 848 & Male & 08-Sep-01 & STSB & 123 & 32 & 154 & 186 & 40 (18) & 1.8 & 2 \\
\hline 1385 & Cow + calf & 08-Sep-01 & STSB & 1 & 1 & 1 & 2 & $2(50)$ & $\mathrm{n} / \mathrm{a}$ & 2 \\
\hline 4172 & Male & 26-Sep-01 & SB & 137 & 54 & 156 & 210 & $63(23)$ & 2.0 & 1 \\
\hline 10826 & Cow + calf & 13-Sep-01 & STSB & $<1$ & 0 & 1 & 1 & $0(0)$ & $\mathrm{n} / \mathrm{a}$ & 1 \\
\hline 23031 & Male & 22-Sep-01 & SB & 161 & 110 & 201 & 311 & $84(21)$ & 2.5 & 1 \\
\hline 23034 & Female & 12-Sep-01 & STSB & 69 & 7 & 60 & 67 & $25(27)$ & 1.3 & 1 \\
\hline
\end{tabular}




\begin{tabular}{|r|c|c|c|c|c|c|c|c|r|r|}
\hline 23037 & Male & $22-S e p-01$ & SB & 64 & 13 & 27 & 40 & $6(13)$ & 0.7 & 11 \\
\hline Total & & & & $\mathbf{1 0 7 8}$ & $\mathbf{6 2 4}$ & $\mathbf{3 6 1}$ & $\mathbf{1 7 0 5}$ & $\mathbf{4 2 7}$ & & 2 \\
\hline
\end{tabular}


Table 2. Coastwise movements of southern right whales, Eubalaena australis, tagged off South Africa, expressed as days post tagging spent in coastal areas, or passing certain coastal features. Gaps in the time line reflect missing days of transmissions. $\mathrm{T}=$ day of tagging.

\section{A. Whales tagged in St Sebastian Bay, 8-12 September 2001}

\begin{tabular}{|l|l|l|l|l|l|l|l|l|l|l|l|l|}
\hline Tag & $\begin{array}{l}\text { Yservark } \\
\text { punt area \& } \\
\text { offshore }\end{array}$ & $\begin{array}{l}\text { Sebastian } \\
\text { Bay }\end{array}$ & De Hoop & Struisbaai & $\begin{array}{l}\text { Round } \\
\text { Cape } \\
\text { Agulhas }\end{array}$ & $\begin{array}{l}\text { Quoin } \\
\text { Point }\end{array}$ & $\begin{array}{l}\text { Walker/ } \\
\text { Area }\end{array}$ & $\begin{array}{l}\text { Round } \\
\text { Bay area }\end{array}$ & $\begin{array}{l}\text { West } \\
\text { Cape } \\
\text { Point }\end{array}$ & $\begin{array}{l}\text { coast } \\
\text { south of } \\
\text { Saldanha }\end{array}$ & $\begin{array}{l}\text { St Helena } \\
\text { Bay area }\end{array}$ & Fate \\
\hline
\end{tabular}

\section{Cow-calf pairs}

\begin{tabular}{|c|c|c|c|c|c|c|c|c|c|c|c|}
\hline 823 & $22-23$ & $\begin{array}{l}\mathrm{T}+14 \\
21-22 \\
24-25+\end{array}$ & $14-20$ & & & & & & & & Signal lost \\
\hline 827 & & $\mathrm{~T}+19$ & $20-27+$ & & & & & & & & Signal lost \\
\hline 843 & & $\mathrm{~T}+4$ & $\begin{array}{l}4-5 \\
16-18\end{array}$ & $\begin{array}{l}5,8-15 \\
19-22\end{array}$ & $<7,23$ & $24-32$ & $33-39+$ & & & & Signal lost \\
\hline 847 & & $\begin{array}{l}T+1 \\
3-28\end{array}$ & $\begin{array}{l}1,28-30 \\
33-42\end{array}$ & $\begin{array}{l}30-32 \\
43\end{array}$ & 43 & $43-51$ & $51-57+$ & & & & Signal lost \\
\hline \multicolumn{12}{|c|}{ Other females } \\
\hline 826 & & $\begin{array}{l}\mathrm{T}+4 \\
8-11\end{array}$ & $\begin{array}{l}5-7 \\
12-13\end{array}$ & & $<16$ & $16-17$ & $22-36+$ & & & & Signal lost \\
\hline 23034 & 4 & $\mathrm{~T}, 8$ & 8 & & $<10$ & 10 & $12-20$ & 24 & $25-28$ & $30-69+$ & Signal lost \\
\hline \multicolumn{12}{|l|}{ Males } \\
\hline 838 & & $\mathrm{~T}+8$ & $9-14$ & 14 & 15 & $16-19$ & $20-47$ & 52 & $56-66+$ & & Signal lost \\
\hline
\end{tabular}




\begin{tabular}{|c|c|c|c|c|c|c|c|c|c|c|c|c|}
\hline 848 & $10-18$ & $\begin{array}{l}T+3 \\
8-9\end{array}$ & $3-4$ & & & & & & & & Left coast & \\
\hline \multicolumn{13}{|c|}{ Unknown } \\
\hline 825 & & $\begin{array}{l}\mathrm{T}+13 \\
27-29\end{array}$ & $\begin{array}{l}14-26 \\
30-33\end{array}$ & $34-37+$ & & & & & & & Signal lost & \\
\hline 839 & & $\mathrm{~T}$ & $1-4$ & $11-12$ & $<8,>12$ & & $15-21$ & & & & Left coast & \\
\hline \multicolumn{13}{|c|}{ B. Whales tagged in Saldanha Bay, 21-26 September 2001} \\
\hline Tag & $\begin{array}{l}\text { Northern } \\
\text { Cape }\end{array}$ & $\begin{array}{l}\text { St } \\
\text { Helena } \\
\text { Bay area }\end{array}$ & $\begin{array}{l}\text { Saldanha } \\
\text { Bay }\end{array}$ & $\begin{array}{l}\text { West } \\
\text { coast } \\
\text { south of } \\
\text { Saldanha }\end{array}$ & $\begin{array}{l}\text { Round } \\
\text { Cape } \\
\text { Point }\end{array}$ & $\begin{array}{l}\text { False } \\
\text { Bay }\end{array}$ & $\begin{array}{l}\text { Walker/ } \\
\text { Sandown } \\
\text { Bay area }\end{array}$ & $\begin{array}{l}\text { Quoin } \\
\text { Point } \\
\text { area }\end{array}$ & $\begin{array}{l}\text { Round } \\
\text { Cape } \\
\text { Agulhas }\end{array}$ & $\begin{array}{l}\text { De } \\
\text { Hoop }\end{array}$ & $\begin{array}{l}\text { St } \\
\text { Sebastian } \\
\text { Bay }\end{array}$ & Fate \\
\hline \multicolumn{13}{|c|}{ Females } \\
\hline 831 & $16-27$ & $\begin{array}{l}2,13 \\
29-35+\end{array}$ & $\mathrm{T}+1,8$ & & & & & & & & & $\begin{array}{l}\text { Signal } \\
\text { lost }\end{array}$ \\
\hline 836 & & & $\mathrm{~T}+1$ & $1-2$ & 3 & 4 & $5-6$ & $7-8$ & 8 & $9-10$ & $10-12$ & $\begin{array}{l}\text { Left } \\
\text { coast }\end{array}$ \\
\hline \multicolumn{13}{|l|}{ Males } \\
\hline 4172 & & $2-4$ & $\mathrm{~T}+1$ & $7-12$ & 21 & $22-27$ & & & & & & $\begin{array}{l}\text { Left } \\
\text { coast }\end{array}$ \\
\hline 23031 & & $7-107$ & $\mathrm{~T}+7$ & & & & & & & & & $\begin{array}{l}\text { Left } \\
\text { coast }\end{array}$ \\
\hline 23037 & & $\begin{array}{l}11-46 \\
59\end{array}$ & $\begin{array}{l}T, 7-9 \\
52\end{array}$ & $1-4$ & & & & & & & & $\begin{array}{l}\text { Left } \\
\text { coast }\end{array}$ \\
\hline
\end{tabular}


Table 3. Offshore movement parameters for five southern right whales, Eubalaena australis, satellite tagged off South Africa, September, 2001. Whale 4172 did not provide enough sequential 'migration' locations to be included in concerted southward migration.

\begin{tabular}{|c|c|c|c|c|c|c|c|c|c|c|c|c|c|}
\hline \multirow[b]{2}{*}{ Tag } & \multicolumn{4}{|c|}{ Initial Departure } & \multicolumn{4}{|c|}{ Whole Offshore Period } & \multicolumn{5}{|c|}{ Concerted Southward Migration } \\
\hline & $\begin{array}{c}\text { Date } \\
\text { departed }\end{array}$ & $\begin{array}{c}\text { Initial } \\
\text { distance } \\
\text { covered } \\
(\mathbf{k m})\end{array}$ & $\begin{array}{l}\text { Number } \\
\text { of } \\
\text { locations }\end{array}$ & $\begin{array}{l}\text { Average } \\
\text { bearing, } \\
\text { distance- } \\
\text { weighted }\end{array}$ & $\begin{array}{l}\text { Days } \\
\text { away } \\
\text { from } \\
\text { coast }\end{array}$ & $\begin{array}{c}\text { Number } \\
\text { of } \\
\text { locations } \\
\text { (number } \\
\text { migrating) }\end{array}$ & $\begin{array}{c}\text { Distance } \\
\text { travelled } \\
(\mathbf{k m})\end{array}$ & $\begin{array}{c}\text { Overall } \\
\text { speed } \\
(\mathbf{k m} / \mathbf{h})\end{array}$ & $\begin{array}{c}\text { Start } \\
\text { position }\end{array}$ & $\begin{array}{c}\text { End } \\
\text { position }\end{array}$ & $\begin{array}{c}\text { Number } \\
\text { of } \\
\text { locations } \\
\text { en route }\end{array}$ & $\begin{array}{c}\text { Distance } \\
\text { travelled } \\
(\mathbf{k m})\end{array}$ & $\begin{array}{c}\text { Overall } \\
\text { Speed } \\
(\mathbf{k m} / \mathbf{h})\end{array}$ \\
\hline 836 & 04-Oct-01 & 731 & 10 & $201.2^{\circ}$ & 67 & $153(98)$ & 5606 & 3.5 & $\begin{array}{l}34.77^{\circ} \mathrm{S} \\
21.27^{\circ} \mathrm{E}\end{array}$ & $\begin{array}{l}44.15^{\circ} \mathrm{S} \\
15.51^{\circ} \mathrm{E}\end{array}$ & 17 & 1285 & 5.7 \\
\hline 839 & 29-Sep-01 & 854 & 5 & $220.5^{\circ}$ & 100 & 143(102) & 8197 & 3.4 & $\begin{array}{l}34.78^{\circ} \mathrm{S} \\
18.37^{\circ} \mathrm{E}\end{array}$ & $\begin{array}{l}53.10^{\circ} \mathrm{S} \\
05.68^{\circ} \mathrm{E}\end{array}$ & 44 & 2468 & 4.4 \\
\hline 848 & 27-Sep-01 & 704 & 12 & $215.7^{0}$ & 105 & $170(43)$ & 5766 & 2.3 & $\begin{array}{l}37.91^{\circ} \mathrm{S} \\
20.50^{\circ} \mathrm{E}\end{array}$ & $\begin{array}{l}48.26^{\circ} \mathrm{S} \\
11.92^{\circ} \mathrm{E}\end{array}$ & 18 & 1534 & 5.1 \\
\hline 4172 & 23-Oct-01 & 733 & 9 & $210^{\circ}$ & 110 & 174 (69) & 6236 & 2.4 & & & & & \\
\hline 23031 & 08-Jan-02 & 727 & 9 & $208.5^{\circ}$ & 53 & $136(50)$ & 3846 & 3.0 & $\begin{array}{l}33.47^{\circ} \mathrm{S} \\
17.67^{\circ} \mathrm{E}\end{array}$ & $\begin{array}{l}52.83^{\circ} \mathrm{S} \\
14.42^{\circ} \mathrm{E}\end{array}$ & 35 & 2464 & 6.5 \\
\hline
\end{tabular}


Table 4. Mean surfacing rates for coastal waters, migration, and feeding for Southern right whales tagged off South Africa, September, 2001 (*significantly higher; **significantly lower).

\begin{tabular}{|c|c|c|c|}
\hline \multirow{2}{*}{ Tag } & \multicolumn{3}{|c|}{ Mean Surfacing/h \pm SD $(n)$} \\
\cline { 2 - 4 } & Coastal & Migration & Feeding \\
\hline 836 & $47 \pm 14.8(35)$ & $73 \pm 23.3(151)^{*}$ & $61 \pm 20.3(83)$ \\
\hline 839 & $61 \pm 17.3(26)$ & $71 \pm 21.5(158)$ & $64 \pm 25.7(57)$ \\
\hline 848 & $67 \pm 12.0(25)^{*}$ & $47 \pm 14.8(69)$ & $51 \pm 14.8(196)$ \\
\hline 4172 & $29 \pm 15.0(57)$ & $47 \pm 29.1(120)$ & $38 \pm 22.0(163)$ \\
\hline 23031 & $40 \pm 11.5(298)^{* *}$ & $46 \pm 15.0(76)$ & $62 \pm 16.9(125)^{*}$ \\
\hline
\end{tabular}




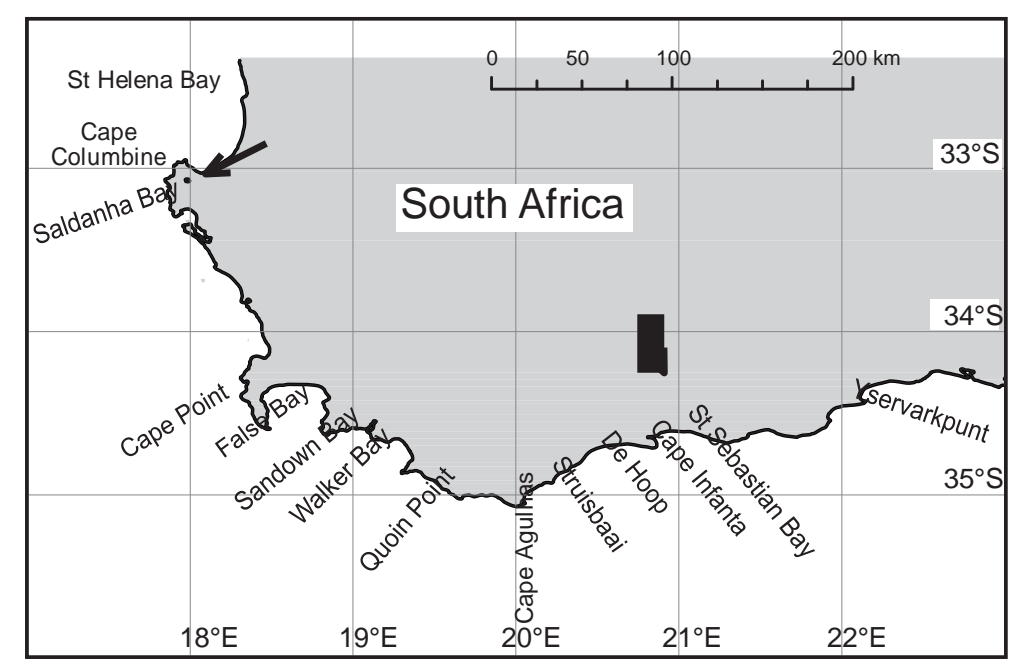

Figure 1. Geographic areas of the south-western coastline of South Africa. Arrows point to the two areas from which tags were deployed. 


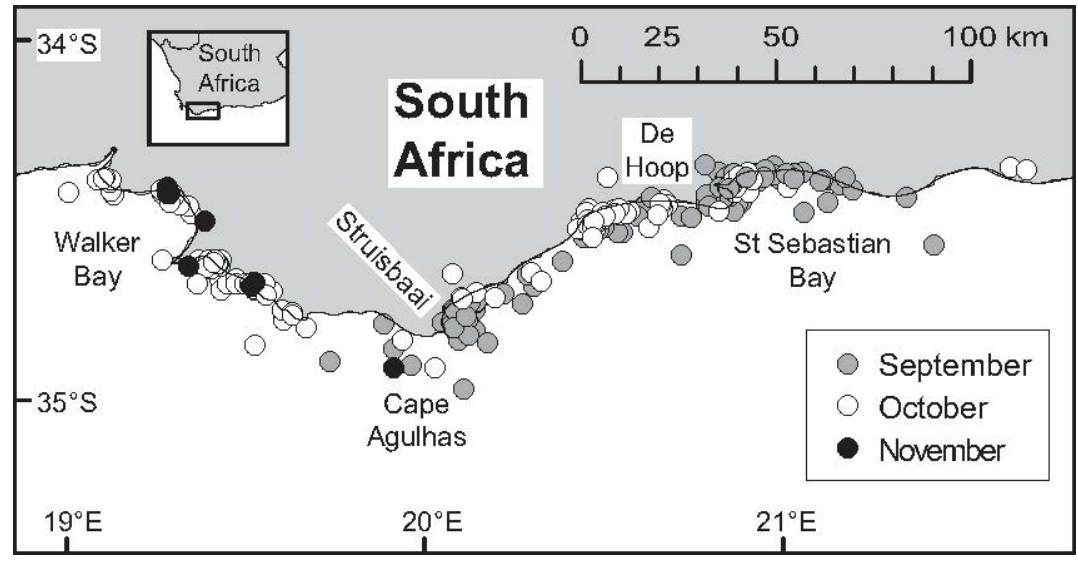

Figure 2. Locations of four right whales, Eubalaena australis, with calves tagged in St Sebastian Bay on the South African coast, September to November 2001. 


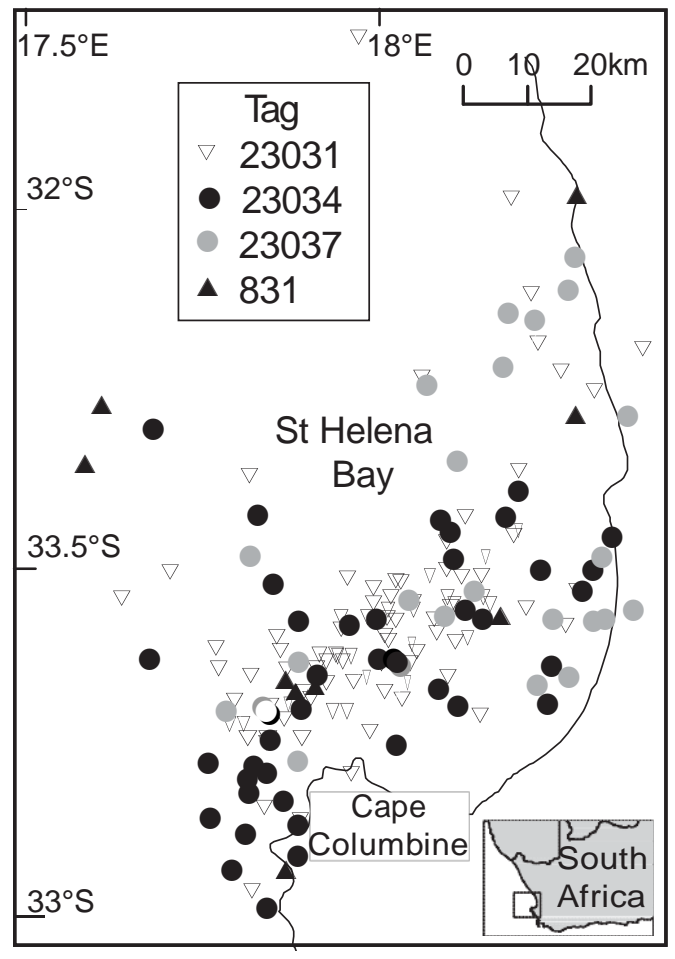

Figure 3. Locations of four satellite-tagged right whales, Eubalaena australis, in St Helena Bay area of South Africa, September 2001 - January 2002. 


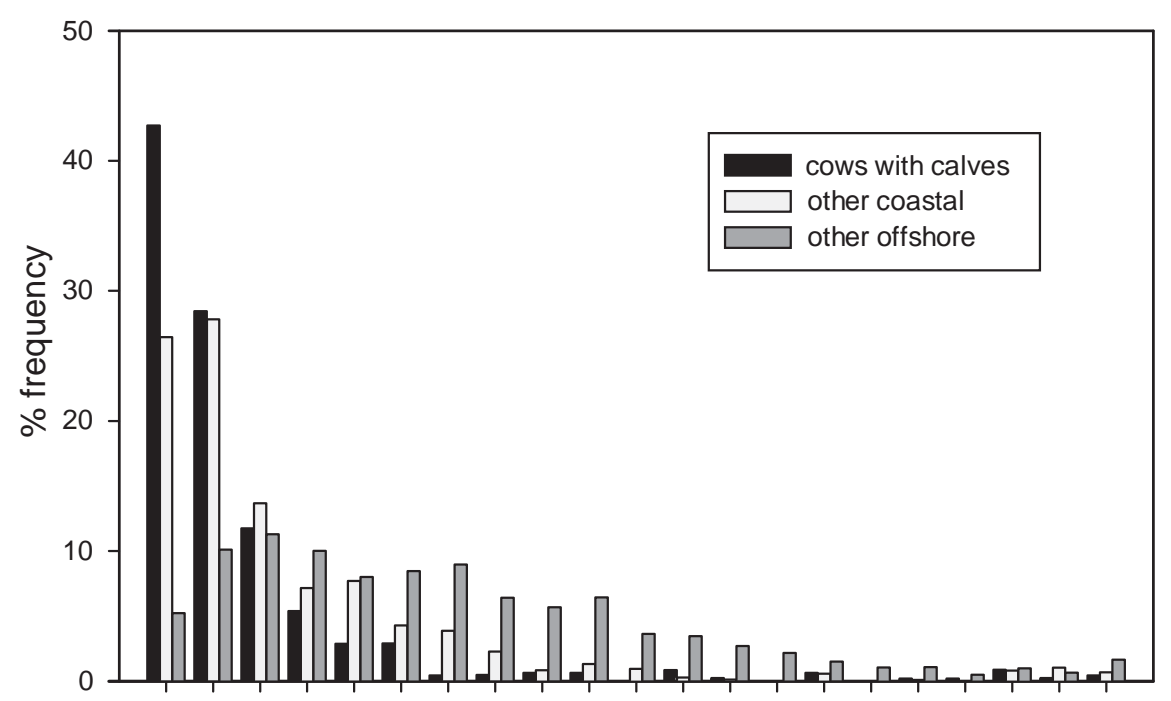

$\begin{array}{lllllllllllllllllllll}0 & 0.5 & 1 & 1.5 & 2 & 2.5 & 3 & 3.5 & 4 & 4.5 & 5 & 5.5 & 6 & 6.5 & 7 & 7.5 & 8 & 8.5 & 9 & 9.5 & 10+\end{array}$

Net speed $\left(\mathrm{km} \mathrm{h}^{-1}\right)$

Figure 4. Percent frequency distribution of net speeds of movement of tagged southern right whales, Eubalaena australis, comparing cow-calf pairs with other classes in coastal and offshore waters. 


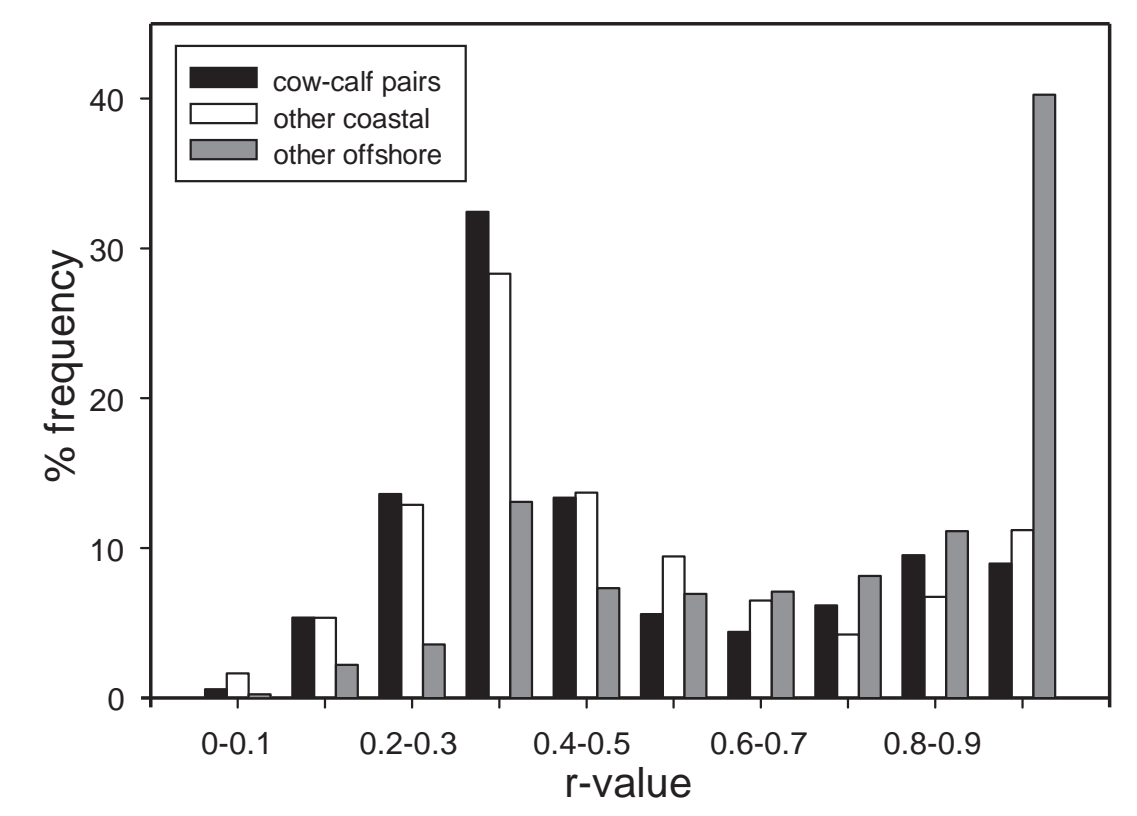

Figure 5. Percent frequency distribution of r-values for direction of movement of tagged southern right whales, Eubalaena australis, comparing cow-calf pairs with other classes in coastal and offshore waters. 


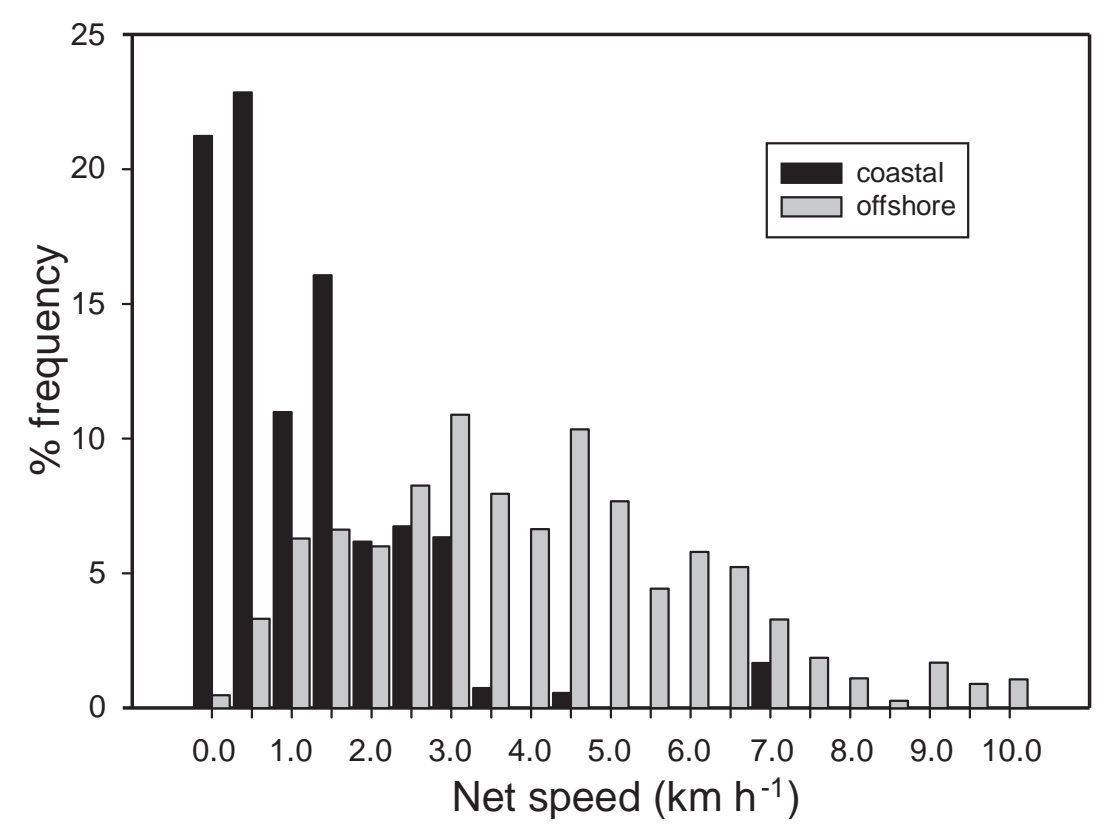

Figure 6. The percent frequency distribution of net speeds of tagged right whales, Eubalaena australis, for locations with r values of 0.9 or more, compared between animals in coastal waters and those offshore 


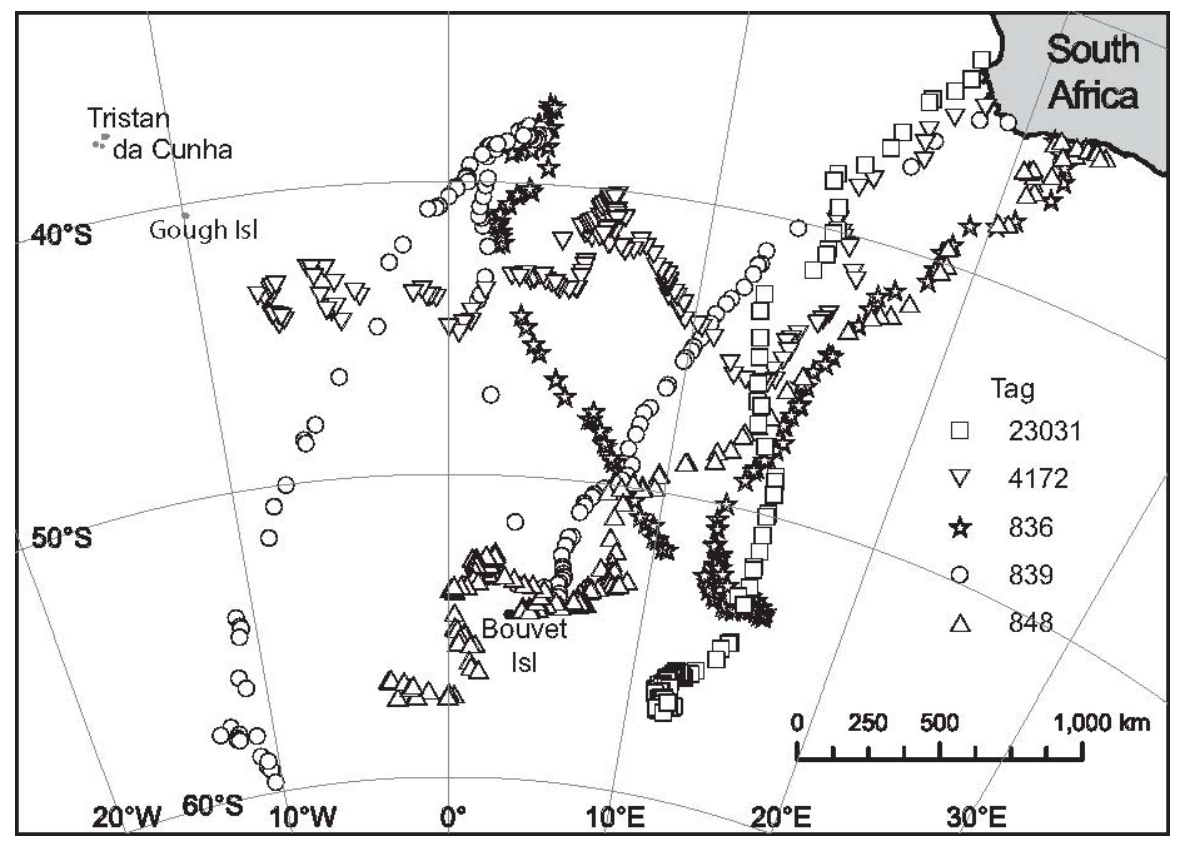

Figure 7. Locations of five tagged right whales, Eubalaena australis, after leaving the South African coastline, September 2001 - March 2002. 


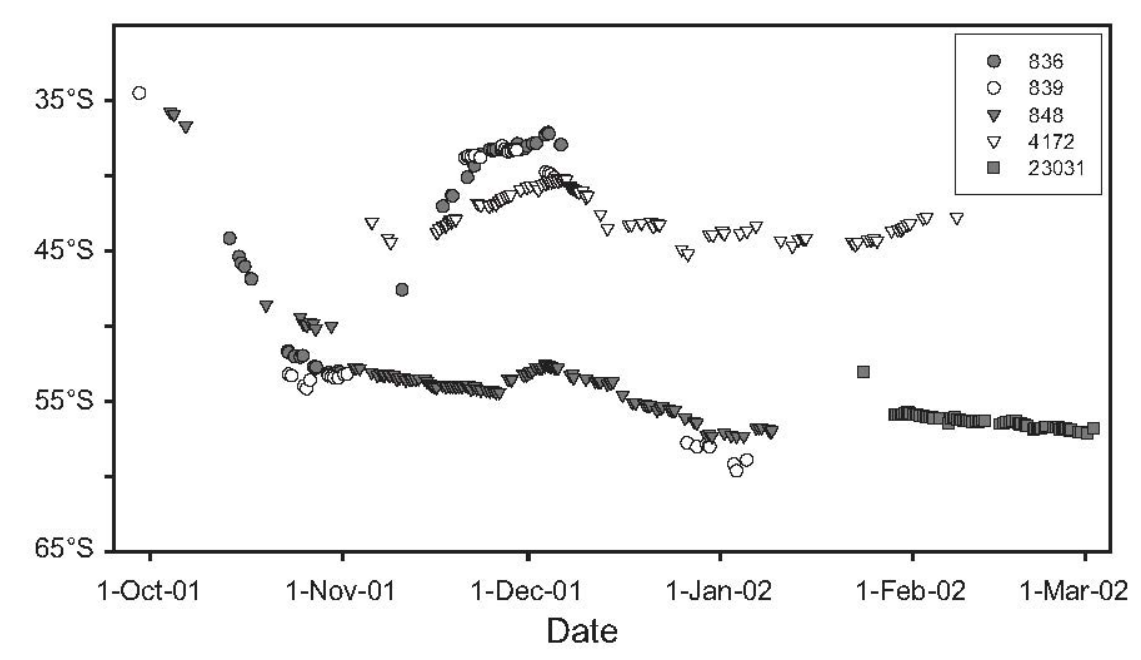

Figure 8. Seasonal trends in the offshore latitudinal distribution of non-migrating locations of tagged right whales, Eubalaena australis, September 2001 - March 2002. 